\title{
Safety award winners describe best practices
}

$\mathrm{T}$ he national death rate of workers in agriculture was second only to that of mining and quarrying in 1996. The National Safety Council publication, Accident Facts, estimates that there were 798 agricultural fatalities nationwide in 1996 , for a death rate of 20.9 per 100,000 workers. For all industries, the death rate was 3.9 per 100,000 .

The publication reports 9.4 per 100 full-time employees in agricultural production suffered nonfatal occupational injury and illness for 1996; the figure was 8.3 for agricultural services, and 7.4 for all industries in the private sector.

"Depending upon the year, the data source, and how broad one makes the categories, California workers suffer between 50 and 70 deaths per year and 15,000 to 17,000 disabling injuries," says William Steinke, director of the UC Farm Safety program. "Agriculture consistently ranks in the top three industries in California, both for fatality rates and injury rates. California victims are young and old; employee, employer, and family; male and female; all ethnic groups, and involved in all commodities."

To get some insight into effective agricultural safety programs, community education specialist Jim Grieshop at UC Davis surveyed safety award winners in California. The respondents named safety training and hazard surveillance as the most important parts of their programs and said one-on-one communication was the most effective way to convey information.

In 1995, the California Farm Bureau Federation in conjunction with the State Compensation Insurance Fund presented the Safety Award for 1994 to 674 California agricultural enterprises that reported no injuries. Grieshop collaborated with the UC Agricultural Health and Safety Center, the Farm Bureau and the State Compensation Insurance Fund to conduct the survey. He received responses from 137 safety award winners, who stated their views on safety, safety practices, their safety programs, sources of safety information, work forces, and farming operations.

Most of the survey participants produce fruit, nuts, field crops and animals.

The respondents thought their safety programs were working well $-42 \%$ rated their programs "somewhat effective" and 58\% rated theirs "very effective." The two single most frequently used practices were safety training and hazard surveillance, with $64 \%$ of the respondents saying that hazard surveillance was very significant to their overall safety program.

Some of their practices included explaining job hazards to employees when they are hired, monitoring the work environment to see that tools are operating properly, inspecting brakes on equipment, keeping protective gear such as dust masks in stock, and making sure warning signs are properly displayed.

"It's interesting to note," says Grieshop, "that reportedly popular programs such as incentive programs were not rated highly in the 'very significant' category."

The respondents employed an average of 7 permanent workers in 1996, but the number ranged from 1 to 45 . They employed an average of 22 seasonal workers but some had as many as 300 . Posters, handbooks and brochures were the most widely used media for communicating safety information to workers. Grieshop says they are likely used because they are readily available, cheap and meet the requirements of safety laws. However, respondents said one-onone communication was the most effective.

While there were no dramatic safety practice revelations apparent from this study, the results do provide a new way of looking at maintaining safety standards in agriculture. Grieshop says, "Respondents believed they can and must control the safety level in their operations and not rely on luck. Their personal commitment to maintaining a safe workplace may play a strong role in the standard that they have set."

During follow-up interviews conducted faceto-face, Grieshop has found individuals who have developed small innovations that make a task safer, innovations that might be passed on to others. For example, one grower noticed puncture wounds on workers' hands so he filed off the sharp tips of the pruning knives.

Grieshop intends to visit safety award winners at their places of business to learn more about how best to communicate work-place safety with workers.

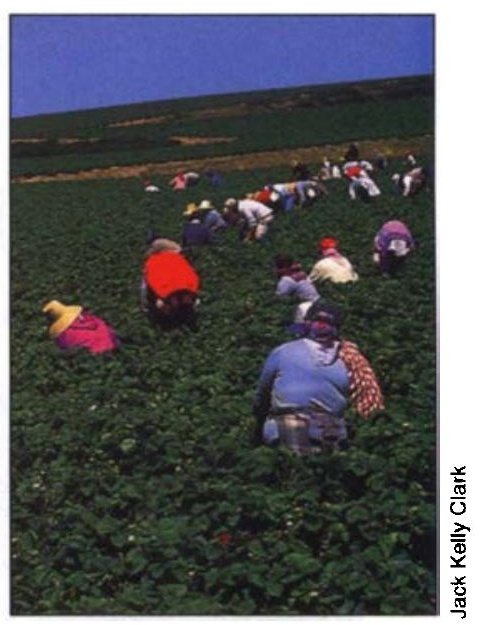

Best practices included explaining job hazards to employees when they were hired.

\section{$64 \%$ of the respondents said that hazard surveillance was very significant}

